\title{
From Living Experience to Poetic Word. Frames and Thresholds of Dante's Divine Comedy
}

\author{
DANIELE MONTICELLI
}

\begin{abstract}
This article concentrates on the functional duplicity of incipits and explicits in the articulation of the planes of living experience, memory, cognition and word in the Divine Comedy. The analysis of beginnings and endings at different structural levels of the poem demonstrates that they work, on one side, as modelizing and universalising frames which delimits the diegetic space conferring a final and stable meaning to narrated events; and, on the other side, as singularizing thresholds which, letting trespass the narrating instance into the diegetic space and the diegetic experience into the narrating instance, problematizes both the separateness and the adequate, harmonious articulation of living experience and poetic word. The article thus unravels Dante's orchestration of limits and openings, totality and excess, sayable and unsayable across incipits and explicits of the Comedy and sketches a new possible research framework for the study of the mise-en-scène of the spatio-temporal distance/dialogue/tension between the embodied experience of Dante-character and the conceptualizing/poetic efforts of Dante-author and its role in the construction of the narrative strategy and the ideological structure of the poem.
\end{abstract}

Keywords: Dante Alighieri, Divine Comedy, incipit, explicit, textual thresholds, narratology

DOI: http://dx.doi.org/10.12697/IL.2013.18.1.17

The identity/difference between Dante as author and Dante as protagonist of his work have occupied a central position in academic research on the Divine Comedy. Although scholars have mainly concentrated on the broader framework of the relations between the text and its historical context, the issue has been also studied in the narratological, phenomenological, cognitive perspective of living experience, memory and writing in first-person narratives. Researchers have asked what is the place of Dante-author in his text and how does he relate to Dante-character. Who does see and who does speak (to employ the Genettean jargon) in the Comedy and which kind of harmony/tension does emerge between experiencing and saying? How do the different planes of 
From Living Experience to Poetic Word. Frames and Thresholds of Dante's Divine Comedy

living, thinking and writing articulate in the text or across text and extratextual circumstances?

The present research tries to re-examine these issues under the new light of a general theoretical question in literary studies: which is the role of beginnings (incipits) and ends (explicits) in literary works? Or, in other words, how do the boundaries of a text manage to separate and/or connect the written and the non-written world, the diegetic space from the extradiegetic circumstances of its creation? As a matter of fact, textual beginnings and ends seem, in their quality of textual boundaries, to be the space within which the above mentioned articulation of different perceptive and cognitive planes tends to become manifest or even thematized. It is, as we will see, in incipits and explicits that experience and thoughts get inscribed into the written text, while the latter can be brought "out of itself".

In what follows I will therefore try to sketch the preliminary framework for a study of the role that incipits and explicits of the Comedy's canticas and cantos play in the articulation of what I will henceforth call the plane of living experience, the plane of saying/writing and the connecting plane of remembering/ thinking. ${ }^{1}$ I will build up my analysis on basic linguistic observations (such as the use of tenses or temporal and spatial deixis) with the aim of keeping generalizations strictly anchored to textual evidence. The analysis will begin from incipits and explicits of the whole Comedy in part 2; in part 3, I will move to incipits and explicits of the three cantica, and finally turn to incipits and explicits of the Comedy's single cantos in part 4. I will consider incipits and explicits respectively the first and the last five terzinas (15 lines) of the Comedy's cantos. This means that beginnings and ends are not understood here as single borderlines, but rather as border-spaces in which the phenomena mentioned above materialize and can be analyzed. ${ }^{2}$

I am of course absolutely aware of the fact that "living experience" and "memory" are of a peculiar kind in the Comedy insofar as they must be considered as the creation of Dante's imagination. At any rate, this doesn't make any difference for my analysis.

2 I have elsewhere considered the importance of shifting from a monodimensional to a multidimensional understanding of boundaries in the analysis of literary texts (see Monticelli 2009). In expanding incipits and explicits I take advantage of the indeterminacy of their delimitation in philological and bibliographical literature. In his dictionary of rhetoric and stylistic, Italian literary theorist Angelo Marchese defines, for instance, "incipit" simply as "the word used to refer to the beginning of a text." (Marchese 1978: 143) 
MONTICELLI

\section{The presents of the Divine Comedy}

An analysis of the different functions of the present tense in Dante's text is the straightest way to determine the different cognitive planes of the Comedy and the complexity of their relations with different experiencing and narrating subjects in the text. Let's consider some passages from incipits and explicits of Inferno's cantos:

(1) See Guido Bonatti. See Asdente, / Who now regrets / not having worked his leather and his thread -- / but he repents too late. See the wretched ones, who gave up needle, [...] But come now... (INF XX, 118-124) ${ }^{3}$

This is the explicit from canto XX and the fourth bolgia (Soothsayers) of Hell's eighth circle (fraud). Vergil is speaking and the present/imperative has a deictic function strictly anchoring the time of events that coincides in (1) with the experience of Dante-character ("see") and other infernal characters (Asdente "regrets" and "repents"), to what linguists call the "speech point". ${ }^{4}$ In the lines quoted above the temporal deictic "now" cooperates with the deictic present to sanction, within Vergil's direct speech - and the same could be said for the direct speech of all the other characters of the Comedy, Dante-character included - the temporal coincidence of word and experience.

At any rate, not all the deictic uses of the present in the Comedy connect the speech point to the experience of Dante-character or other characters in the text. The next lines introduce a different kind of deictic present:

(2) To tell how strange the new place was / I say we reached a barren plain (INF XIV, 7-8)

Even if it maintains its deictic value, the present does not coincide here with the time of Dante-character's experience, but rather with the time of Dante-author, referring not so much to his experience, but rather to his saying/writing. If,

3 I use here and henceforth Robert and Jean Hollander's translation of the Comedy because it is very clear and closely reproduces the stylistic choices of the Italian text which interest me. However, my analysis always draws on Dante's original and I will signal relevant divergences in the translation.

4 See the classic Reichenbach 1947. For a description of the different uses of the present tense in Italian see, GGICII: 62-70. 
From Living Experience to Poetic Word. Frames and Thresholds of Dante's Divine Comedy

despite the absence of quotation marks in the text, we decided to consider also the deictic present in (2) as occurring within some kind of direct speech, we would be forced to conclude that here the speaker cannot be one of the characters, but the author himself who (implicitly) addresses his readers. The gap between the plane of saying and that of experience is stressed in (2) by the close juxtaposition of the present tense ("I say") and the simple past ("we reached").

The alternation of deictic presents with different reference points is typical of literary works with a homodiegetic/extradiegetic narrator (Genette 1983) Dante-author (extradiegetic) narrates his own story (homodiegetic), thus creating his narrative alter-ego, the "Dante-character". The deictic present thus splits, acquiring two different functions in the Comedy: on the one hand, it sanctions the coincidence between word and experience (as in (1)), on the other hand, it introduces a temporal and cognitive gap between the act of saying/writing and that of living/experiencing (as in (2)). As we will see, Dante obtains different narrative effects masterfully alternating coincidences and separations between the plane of experience and the plane of narration.

Non-deictic uses of the present tense are also very common in the Comedy. Such is the case when the present is used outside characters' direct speech in order to describe different places of the three worlds of afterlife and their inhabitants. The incipit of Inferno's canto V introduces, for instance, the figure of Minos, describing its features and actions in the present tense:

(3) There stands Minos snarling, terrible. / He examines each offender at the entrance; / judges and dispatches as he encoils himself (INF V, 4-6)

We can define this use of the present as atemporal (GGIC: 63-65), because in (3) the (deictic) relation between described events and the moment of enunciation is irrelevant; differently from (1) and (2) the verbs in the present tense of (3) do not refer to experiences/events which are characterized by the singularity of a hic et nunc. They, on the contrary, describe habitual situations/actions which repeat and will continue to repeat so long as the three worlds of the afterlife have existed and will exist.

Another kind of atemporal use of the present is observable in Dante's famous similes, which often have a proverbial value, describing things which have always been and will always be in the same way:

(4) As the falcon that has long been on the wing -- / and, without sight of lure or bird / makes the falconer cry out: 'Oh, you are coming down!' -- / 
MONTICELLI

descends, weary, with many a wheeling, / to where it set out swiftly [...] so Geryon set us down at the bottom (INF XVII, 127-133)

The combined use of the deictic present and the atemporal present is a fundamental poetic device of the Comedy that importantly contributes to institute that parallelism between individual experience (of Dante-character/author) and universal (human) experience which has been highlighted by several scholarly works on Dante's poem. ${ }^{6}$ Concluding this research (part 5), I will describe a further function of the present tense in the Divine Comedy which is particularly interesting for the topic discussed here.

\section{Beginnings and ends: textual frames or thresholds?}

Traditional interpretive approaches to the Comedy usually focus on the diegetic level of the work - the sequel of events in Dante's journey through the worlds of afterlife as a symbol of the path of individual redemption and universal salvation in which the deictic present seems to merge into the atemporal one. From this point of view, it is possible to claim that the Divine Comedy is one of those stories where the beginning (together with the entire diegetical developments) finds its ratio and justification only in the end. Dante-author clearly states the teleological nature of his enterprise in the incipit of Inferno's first canto:

(5) But to set forth the good I found / I will recount the other things I saw (INF I, 8-9)

Inferno's canto I (and consequently the Comedy as a whole) presents us therefore with what we could describe as a "double incipit": while Dante-character begins getting lost in the wood, Dante-author begins foretelling (with the deictic future "I will recount") the final end ("the good") which actually provoked ("to set forth") the narration of the other experiences of his journey ("the other

\footnotetext{
5 It is interesting to notice that Dante employs also many "historical" similes which clearly relate to his times as in the incipit of Inferno's canto XV ("As the Flemings between Wissant and Bruges, fearing the tide that rushes in upon them / erect a bulwark to repel the sea...). In such cases the deictic relation between the speech point and the historical experience of Dante-author is stronger than in (4), but still much weaker than in the proper deictic uses illustrated in (1) and (2).

6 See for instance Contini 1970: 35.
} 
From Living Experience to Poetic Word. Frames and Thresholds of Dante's Divine Comedy

things"). The qualitative gap between the "other things" and the arrival to the "good", which ends and gives a meaning to the story, is marked by the shift of the grammatical subjects and tenses between the incipit/explicit of Inferno and incipit/explicit of Paradiso, that means between the beginning and the end of the Comedy as a whole:

(6) Midway in the journey of our life / I came to myself in a dark wood... (INF I, 1-2)

The glory of Him who moves all things (PAR I, 1)

Then we came forth, to see again the stars (INF XXXIV, 139)

the Love that moves the sun and all the other stars (PAR XXXIII, 145)

The shift from the deictic human subject ("I","we") to the divine one ("Him who", "the Love") and from the simple past (positioning the experience of the characters in relation to the speech point of Dante-author's writing) to the atemporal present (independent from any particular experience or human deictic reference point) marks the accomplishment of the "transhumanizing" journey in the poem.

This progressive movement from historical to eschatological time is doubled in the Comedy's incipit and explicit by the coincidence of the existential and the universal levels of Dante's journey. This is accomplished through personal deixis markers. If, opening the Inferno and the whole Comedy (see (6) above) Dante lets the first-person singular ("I came to myself") meet the plural ("our life"), in the famous lines of the contemplations of the divine circles in the explicit of the Paradiso,

(7) That circling which [...] seemed, / within itself and its very color, / to be painted with our likeness, / so that my sight was all absorbed in $i^{7}$ (PAR XXXIII, 127-132)

Dante closes the last cantica and the whole Comedy reaffirming, through the substitutability of "our" and "my", that coincidence between individual and universal human experience whose condition of possibility seems to lay exactly in the essential relation between beginning and end (of Dante's and the

A closer translation of the last line would be "because my face was thoroughly depicted in it" [per che'l mio viso in lei tutto era messo]. 
human journey) and in the meaning that such relation confers on the journey as a whole.

What has been so far said about the function of incipit and explicit of the Comedy can be conceptualized through Yuri Lotman's definition of textual beginnings and ends as "limits" or "frames" (Lotman 1977: 209-217). According to Lotman, the textual frame is "an indispensable condition of any artistic work" as a finite model of the infinite world. This means that beginnings and ends have, firstly, a fundamental modelling function allowing the fixation of a meaning which may otherwise get lost in the unlimited and open experience of the real, extra-artistic world. Secondly, the textual frame (beginning+end) allows an artistic work, as we have seen in the case of the Divine Comedy, to be universalized, despite the singular character of its narrative. Lotman defines this as the "dual nature of an artistic model": "while reflecting a separate event, it simultaneously reflects a whole picture of the world; [... That's why a good or bad ending is so significant for us: it attests not only to the conclusion of some plot, but also to the construction of the world as a whole" (Lotman 1977: 216). The frame constituted by incipits and explicits therefore transforms the hic et nunc in an "everywhere and always", virtually re-absorbing the extra-diegetical (the infinite world) into the diegetical (its finite model).

However, a too strict adherence to this understanding of beginnings and ends risks to conceal a certain degree of functional ambiguity that the above mentioned oxymoric split of the Comedy's incipit already started to revealed. If they can be conceived as the securing boundaries of the frame delimiting the inside from the outside, incipits and explicits always remain also thresholds (see Genette 1997), that is to say liminal spaces of communication between the internal and the external, zones of indeterminacy where the separateness of the diegetic space is called into question and the possibly dissonant ensemble of its enunciative instances revealed. Textual thresholds do not necessarily coincide with the singular beginning or end of an entire work. They rather cross it, making problematic that self-enclosure which, according to Lotman, warranted the meaning and the universal import of the artistic work.

In the Comedy, incipits and explicits often function as such thresholds between different spaces and times, becoming the points of (dis)articulation between the different narrative and cognitive planes described at the beginning of this article. With a high degree of generalization, we can preliminarily describe incipital and explicital thresholds as the places where the voice of Dante-author tends to get directly audible and the relations between experience, saying/writing and remembering/thinking are explicitly thematized in the Comedy. 
From Living Experience to Poetic Word. Frames and Thresholds of Dante's Divine Comedy

\section{Inferno's, Purgatorio's and Paradiso's incipits and explicits}

The functional ambivalence of artistic beginnings and ends is particularly evident in the split of incipits and explicits of the Comedy three canticas which present us with the instrumental duplicity of Dante's attitude toward his poetic enterprise. On the one hand, Dante seems to follow the tradition of the epic proem and repeats in canticas' incipits the epic poet's classical gesture of the invocation to the Muses. From our point of view, this kind of incipit is aimed at investing the poetic word and consequently the saying/writing of Danteauthor with authority, legitimacy and indisputability. This means that, as it happens in the tradition of epics, after the invocation to the Muses, the narrating instance (with all its deictic instrumentarium) becomes invisible and is not resumed until, in some cases, the work's explicit. ${ }^{8}$ This kind of narrative strategy, which sets a clearly framing boundary between the level of (once and for all empowered) saying/writing and the level of narrated experience, is adopted by Dante most straightforwardly in incipit and explicit of the Purgatorio which starts as follows:

(8) To run its course through smoother water / the small bark of my wit now hoists its sail / Here from the dead let poetry rise up / O sacred Muses, since I am yours. / Here let Calliope arise / to accompany my song with those same chords... (PUR I, 1-10)

Temporal (the present tenses "hoists", "am", "now"), spatial (the adverb "here”) and personal (the possessive "my") deixis refer here to the instance (Danteauthor), the time and the space of poetic saying (or, more precisely, "singing") as distinguished from the experience of Dante-character. At the end of the narration of Dante-character's journey in the Purgatory, the explicit of the cantica symmetrically resumes the topic of writing, bringing us once again outside the diegetic space/time towards the narrating instance, and directly addressing the reader:

(9) If, reader, I had more ample space to write, / I should sing at least in part the sweetness / of the drink that never would have sated me, / but, since

8 Greimasian semioticians have employed the notions of embrayage and débrayage in the analysis of this alternation of inscription, deployment and hiding of the instances of enunciation in the literary text (see Greimas, Courtés 1982). 
MONTICELLI

all the sheets / readied for this second canticle are full, the curb of art lets me proceed no farther. (PUR XXXIII, 136-141)

In addition to personal and temporal deixis, the demonstrative "this" points here to a spatial referent obviously external to the diegesis and rather attached to Dante-author and his reader. If in the incipit (see (8)) Dante-author could rely on a series of potentialities ("wit", "poetry", "song"), in the explicit he can already represent their full actualization ("all the sheets", "this second canticle"). The cantica opened with the investment of the poetic word and closes with another declaration of self-assurance on the part of the poet who is confident of the expressive power and abundance of his poetry ("I had more ample space"). At the same time, the possible insecurity generated by the partiality of the word ("in part") and the consequent dissatisfaction of the poet and his reader ("never would have sated me") is dispelled by Dante's reference to the artistic norm ("the curb of art"), which prescribes, legitimizes and makes thus harmless the closure of the cantica.

Purgatorio is, compositionally and poetically, the median, less liminal part of Dante's Comedy. The experience of Dante-character is here emotionally less intense, more stable, the word which reproduces it safer and the textual boundaries more impermeable and solid, functionally equivalent to Lotmanian textual frames. Turning to incipits and explicits of Inferno and Paradiso, the picture importantly changes. It emerges there what Dante describes in different passages (mainly cantos' incipits and explicits) of the Comedy as the difficulty or even impossibility of adequately articulating living experience and memory in the poetic word. This articulatory impasse is attributed by Dante to the limits of the human mind while facing the most extreme experiences:

(10a) Who, even in words not bound by meter, / and having told the tale many times over, / could tell the blood and wounds that I saw now? / Surely every tongue would fail / for neither thought nor speech / has the capacity to hold so much. (INF XXVIII, 1-6)

(10b) O how scant is speech, too weak to frame my thoughts. / Compared to what I still recall my words are faint - / to call them little is to praise them much. (PAR XXXIII, 121-123)

Dante describes in these incipits/explicits what we could define, borrowing a concept of contemporary psychology, a "cognitive dissonance": the unity between the different levels of human experience gets lost, the passage from perception 
From Living Experience to Poetic Word. Frames and Thresholds of Dante's Divine Comedy

to memory, from memory to cognition, and from cognition to communication becomes problematic and interrupts or generates dangerous short-circuit at different transition points. In contrast with what we have claimed for the case of the Purgatorio, diegetic boundaries become highly instable in $10 \mathrm{a}-\mathrm{b}$ - on the one hand, they are here threshold (not frames) the troubled crossing of which always implies a certain degree of uncertainty and indeterminacy; on the other hand, they become permeable and they cannot warrant any more that separation between different temporal and cognitive levels which is also the essential prerequisite for their correct articulation. If I have so far spoken of incipits and explicits as frames or thresholds, we could imagine them here also as defected membranes or filters whose network tends to stretch and flake off with consequent dysfunctions in the transactions between the inside and the outside. The explicit thematization of such separational dysfunctions doubles, in the opening and closure of Inferno and Paradiso and therefore of the whole Comedy, the teleological framing of the diegetic space described above (see part 2), introducing into it a kind of precariousness which becomes one of the main sources of narrative tension in the Comedy. Let us observe this more closely.

The incipit of the first canto of Inferno immediately introduces the difficulty of adequately relating experience and word. The problem seems to derive here from the impossibility of taking the right distance (through the mediating function of the intellect), because the Dante-character's experience trespasses the diegetic boundary and invades the extradiegetic space of Dante-author's thoughts:

(11) Ah, how hard it is to tell / the nature of that [esta] wood, savage, dense and harsh -- / the very thought of it renews my fear [...] How I came there I cannot really tell (INF I, 4-10)

The renewed fear (which arises from the interference of Dante-character's experience in Dante-author's thought) creates in these lines a short-circuit mirrored on the linguistic level by deictic devices: in the original the wood is not quella (deictic demonstrative referring to the position of Dante-character), but esta (referring to the position of Dante-author), ${ }^{9}$ and the close repetition of the personal pronoun "I" tends in the same way to confound the temporal plans separated by the present tense ("cannot", where "I" refers to Dante-author) and

9 The English translation "that" here "normalizes" the deictic situation, thus weakening the short-circuit. 
the simple past ("came", where "I" refers to Dante-characters). This lack of adequate distance, that I have described through the figure of the "short-circuit", is responsible for the difficulty to transform experience into words ("I cannot really tell").

Italo Calvino has described this difficulty as "the anxiety in face of the question of beginning and ending": "we are given a possibility to say everything, in every possible way; and we must arrive to say one thing in a particular way" (Calvino 1995: 750, 734; my translation - D. M.). The analogous Dante's anxiety as expressed in the lines reported in (11) makes incipits and explicits permeable in both directions. They are not only the places where incursions of diegetic experience into the territory of poetic reflection and creation take place and are illustrated. In an opposite and, at the same time, complementary way, the permeability of textual thresholds makes of incipits and explicits also the spaces where the narrating instance and its anxieties never cease to insinuate into the infernal experience, instead of maintaining their distance and being silenced to give exclusive room to the deployment of the diegetic world.

Inferno and the whole Comedy thus open, contrary to the Purgatorio, with a problematization of poetic saying/writing which calls into question its authority and legitimacy. The invocation to the Muses arrives only later, in the incipit of Inferno's second canto,

(12) O Muses, O lofty genius [ingegno] aid me now / O memory [mente] that set down what I saw, here shall your worth be shown (INF II, 7-9)

and is completely dedicated to the search for the correct articulation between experience ("saw"), memory, intellect ("genius") and writing ("set down"). In the line preceding the ones quoted in (12) - "which memory [mente], unerring, shall retrace [ritrarrà]", INF II, 6 - Dante had re-affirmed his belief in the power of the poetic word. It is as if the incipit of the second canto wanted to exorcize ${ }^{10}$ the incipit of the first canto, thus reinstating the frame of the whole work which the "anxiety of saying" had eroded even before, we could argue, properly beginning.

At any rate, Inferno never ceases to be the place where boundaries are not only, and by definition, diegetically ${ }^{11}$ but also narratologically violated. Thus, in the explicit of the cantica the anxiety of saying returns, and the canto XXXIV

10 Calvino evidences in this sense the "ritual" function of the invocation to the Muses in the incipit of literary works (Calvino 1995: 737).

11 On Dante's Hell as the place of violation of boundaries see Lotman 2000: 177-185. 
From Living Experience to Poetic Word. Frames and Thresholds of Dante's Divine Comedy

opens with the same upsetting trespassing of infernal experience (once again "fear") from the diegetic to the extradiegetic space with which Inferno's canto I had opened: "Now --- and I shudder as I write it out in verse --- I was where the shades were wholly covered" (INF XXXIV, 10-11). Already before this, the whole incipit of canto XXXII - which introduces Dante-character's arrival to Cocytus that is, from a topographical point of view, the explicit from the Hell - had been dedicated to a new brief invocation to the Muses framed by longer meditations about the difficulty of adequately articulating experience and poetic word which means here finding the right linguistic equivalents ("that the telling be no different from the fact") to the infernal "bottom of the Universe":

(13) If I had verses harsh enough and rasping / as would befit this dismal hole / upon which all the other rocks weigh down, / more fully would I press out the juice / of my conception. But, since I lack them, / with misgiving do I bring myself to speak. / It is no enterprise undertaken lightly - / to describe the very bottom of the universe - / nor for a tongue that still cries 'mommy' and 'daddy.' / But may those ladies who aided Amphion / to build the walls of Thebes now aid my verse, / that the telling be no different from the fact. (INF XXXII, 1-12)

Incipit and explicit of the Paradiso present us with an analogous situation. The third cantica thus begins with an anxious thematization of the power of the word:

(14) I was in that heaven which receives / more of His light. He who comes down from there / can neither know nor tell what he has seen, / for, drawing near to his desire, / so deeply is our intellect immersed that memory cannot follow after it. (PAR I, 4-9)

The contrast here is very strong with the explicit of the preceding canto, the XXXIII and last of the Purgatorio (see (9) above), where Dante affirmed the exuberant abundance of the poetic word. Dante-author's violation of diegetic boundaries is here aimed to represent just like in Inferno the impossibility of adequately articulating experience, memory, thought and word, but the reason 
of Dante's anxiety has changed here: it is not the infernal paura, but the closeness to the object of human desire (desire) and love. ${ }^{12}$

Instead of offering a final recomposition of the cognitive dissonance and re-establishment of a harmonic relation between different narrative and cognitive planes, Canto XXXIII of Paradiso, the explicit of the cantica and of the whole Comedy, presents us with an unprecedented number of authorial intrusions (20 lines) which brings the problematization of the word's power to its highest peak just while closing the poem. Here are some illustrating lines:

(15) From that time on my power of sight exceeded / that of speech, which fails at such vision, / as memory fails at such abundance. (PAR XXXIII, 55-57)

Now my words will come far short / of what I still remember, like a babe's / who at his mother's breast still wet his tongue. (PAR XXXIII, 106-108)

O how scant is speech, too weak to frame my thoughts. / Compared to what I still recall my words are faint - / to call them little is to praise them much. (PAR XXXIII, 121-123)

At any rate, just like it happened in Inferno, also Paradiso presents us with split incipits. In fact, the second canto of the Paradiso contains not precisely an invocation, but still a brief reference to the Muses (PAR II, 8-9), while the problematizing incipit of the first canto (see (14)) is followed by a long invocation ( 9 lines) to Apollo and the "Holy power" (virtù divina):

(16) O holy power, if you but lend me of yourself / enough that I may show the merest shadow / of the blessed kingdom stamped within my mind / you shall find me at the foot of your beloved tree, / crowning myself with the very leaves / of which my theme and you will make me worthy. (PAR I, 22-27)

The invocation to divine help is repeated in the last canto of the Paradiso:

12 In the last canto of the Paradiso, Dante-character's experience at the presence of the desired object similarly trespasses into Dante-author's saying: "I believe I understood the universal form / of this dense knot because I feel my joy expand, rejoicing as I speak of it" (PAR XXXIII, 91-93), where the "rejoicing as I speak of it" redoubles and reverts the interference at the explicit of the Inferno, "and I shudder as I write it out in verse". 
From Living Experience to Poetic Word. Frames and Thresholds of Dante's Divine Comedy

(17) O light exalted beyond mortal thought, / grant that in memory I see again / but one small part of how you then appeared / and grant my tongue sufficient power / that it may leave behind a single spark / of glory for the people yet to come, / since, if you return but briefly to my mind / and then resound but softly in these lines / the better will your victory be conceived. (PAR XXXIII, 67-75)

While progressively shifting from classical referents to symbols of the Christian divinity, Paradiso's invocations continues, just like it happened in Inferno, to be framed by references to the problematicity of the word and the anxiety of saying (see (14) and (15)). Anyway, in Paradiso Dante no more hesitates to show his confidence in the accomplishment of the poetic enterprise (the "beloved laurel"); the achievement of the moral "good" foreseen in the incipit of the Inferno has to be sanctioned by Dante's ability to conclude his work, reinstating the frame within which the articulation of experience, memory, thought and word can be set right. Thus, in the second canto and redoubled incipit of the Paradiso, Dante-author is already able to become the guide of his own readers just like Vergil and Beatrice had been the guides of Dante-character in the three worlds of afterlife:

(18) O you eager to hear more, / who have followed in your little bark / my ship that singing makes its way, turn back if you would see your shores again. / Do not set forth upon the deep, / for losing sight of me, you would be lost. / The seas I sail were never sailed before. (PAR II, 1-7)

The interpolation of Dante-author's voice creates here a perfect equivalence between the diegetic level (Dante-character lead by Vergil and Beatrice) and the extradiegetic level of writing/reading (the "singing" Dante-author and the "hearing" readers): the journey of the latter recapitulates the journey of the former, closing the circle and sanctioning its meaning. With the accomplishment of the poetic work, the adequacy of the transformation of (Dante-character's) experience into (Dante-author's) thought and word is demonstrated by the "reincarnation" of (Dante-author's) word into (his reader's) thought and experience. However, if in the incipit/explicit of the Purgatorio the "small bark" of the poet's "wit" is said to navigate more calmly thanks to the "smoother water" and the "curb of art" (see (8) and (9) above), in the incipit of Paradiso's second canto (see 18) it is, on the contrary, the absolute unpredictability of the waters to be 
MONTICELLI

crossed that sanctions the unprecedented exceptionality of Dante's word and work.

Interpolations of the narrating voice in incipits and explicits of the single cantos

The analysis of incipits and explicits of the single cantos of the Comedy confirms what has been observed so far about incipits and explicits of the three cantica. The difference between incipits and explicits of Inferno and Paradiso, which thematize the difficulties in the articulation of experience, memory/intellect and word, and the incipits and explicits of the Purgatorio, where there are no traces of such problematization, manifests itself also while comparing interpolations of the narrating voice in incipits and explicits of the single cantos of the three canticas.

Table 1. Interpolations of Dante-author's voice in incipits and explicits of Comedy's cantos.

\begin{tabular}{|c|c|c|c|c|c|c|}
\hline \multirow[b]{2}{*}{ CANTO } & \multicolumn{2}{|c|}{ INFERNO } & \multicolumn{2}{|c|}{ PURGATORIO } & \multicolumn{2}{|c|}{ PARADISO } \\
\hline & Incipit & Explicit & Incipit & Explicit & Incipit & Explicit \\
\hline I & $4-10$ & & $1-12$ & & $4-15$ & \\
\hline II & 6,9 & & & & $1-15$ & \\
\hline III & & 132 & & & & \\
\hline IV & 7 & $\begin{array}{c}145-47 \\
149^{*}, 151^{*}\end{array}$ & & & 8 & \\
\hline V & 7 & & & & & 139 \\
\hline VI & $5-7^{*}$ & 113 & & 138 & & \\
\hline VII & & & & & & \\
\hline VIII & 1 & & & & & \\
\hline IX & & & & & & \\
\hline $\mathrm{X}$ & $1-3^{*}$ & & & & 7,10 e $13^{*}$ & \\
\hline XI & & & & & & \\
\hline XII & & & & & & \\
\hline XIII & & & & & $1-10$ & \\
\hline XIV & $7-8$ & & & & & 130,136 \\
\hline XV & $1-3^{*}$ & & & & & \\
\hline XVI & 12 & $127-9$ & & & 6 & \\
\hline
\end{tabular}


From Living Experience to Poetic Word. Frames and Thresholds of Dante's Divine Comedy

\begin{tabular}{|c|c|c|c|c|c|c|}
\hline \multirow[b]{2}{*}{ CANTO } & \multicolumn{2}{|c|}{ INFERNO } & \multicolumn{2}{|c|}{ PURGATORIO } & \multicolumn{2}{|c|}{ PARADISO } \\
\hline & Incipit & Explicit & Incipit & Explicit & Incipit & Explicit \\
\hline XVII & & $123^{*}$ & 1 & & & \\
\hline XVIII & 6 & & & & $9-13$ & \\
\hline XIX & 5 & 121 & & & $7-9$ & \\
\hline $\mathrm{XX}$ & $1-3$ & & & 147 & & v 145 \\
\hline XXI & 3 & & & & & \\
\hline XXII & & & & & & \\
\hline XXIII & & & & & 17 & \\
\hline XXIV & & & & & & \\
\hline $\mathrm{XXV}$ & & $143-4$ & & 136 & $1-9$ & \\
\hline XXVI & & & & & & \\
\hline XXVII & & & & & & \\
\hline XXVIII & $1-6$ & & & & 10 & \\
\hline XXIX & & & & & & \\
\hline $\mathrm{XXX}$ & & 135 & & & & \\
\hline XXXI & 5 & & & & & $136-38$ \\
\hline XXXII & $1-15$ & & 14 & & & \\
\hline XXXIII & & & & $136-41$ & & \\
\hline XXXIV & 10 & & & & & \\
\hline TOTAL & $\begin{array}{r}68 \text { lines i } \\
\text { (of whic } \\
\text { pre }\end{array}$ & $\begin{array}{l}22 \text { cantos } \\
12 \text { hist. } \\
\text { ent) }\end{array}$ & 24 lines & 7 cantos & $\begin{array}{r}71 \text { lines } \\
\text { (of wh } \\
\text { pre }\end{array}$ & $\begin{array}{l}15 \text { cantos } \\
3 \text { hist. } \\
\text { nt) }\end{array}$ \\
\hline
\end{tabular}

${ }^{*}=$ historical present (see 5 below).

Table 1 offers a quantitative comparison of the lines in which the narrating voice (with deictic present, present perfect, or future tenses referring to Danteauthor's speech point) makes itself audible in the incipits and explicits of cantos of the whole Comedy. As the table shows, the high frequency of the manifestations of Dante-author's voice in incipits and explicits of Inferno's and Paradiso's cantos clearly opposes its very modest appearances in incipits and explicits of Purgatorio's cantos. This confirms the correlation observed above between the "anxiety of saying" (thematization of dysfunctions in the articulation of experience, memory/intellect and word) and the uncertainty of the boundaries between diegetic world and extradiegetic saying/writing situation (interpolations of Dante-author's voice). 
MONTICELLI

\section{The historical present}

Before concluding, I will consider a particularly interesting solution employed by Dante in a few incipits and explicits of Inferno and Paradiso as a way of overcoming difficulties in the articulation of experience and word. This solution is based on what linguists define as "the historical present" that is the present tense used in the narration of past events. ${ }^{13}$ If we employ the criteria suggested at the beginning of this article while distinguishing the functions of the present tense in the Divine Comedy, the historical present has to be considered as a separate type. Contrary to the interpolations of Dante-author's voice considered in 4, the historical present is temporally anchored within the boundaries of the diegetic space; however, it does not figure within the direct speech of the characters (Dante-character included), it rather substitutes the simple past in the narration of their experience and actions. Here are some examples:

(19) The company of six falls off to two / and my wise leader brings me by another way / out of the still, into the trembling air. / And I come to a place where nothing shines (INF IV, 148-151)

With my returning senses that had failed / at the piteous state of those two kindred, / which had confounded me with grief, / new torments and new souls in torment / I see about me, wherever I move, / or turn, or set my gaze. / I am in the third circle of eternal hateful rain, cold and leaden (INF VI, 1-8)

Now my master takes a hidden path / between the city's ramparts and the torments, / and I come close behind him

(INF X, 1-3)

If we compare the uses of the present tense in (19) with the distinction suggested in part 1 between the deictic present of the character (see (1) above) and the deictic present of the author (see (2) above), we could say that the historical present marks the impossibility of distinguishing between the two; it opens, in other words, a zone of indetermination between the deictic uses of the present in the Comedy. If it was Dante-character to speak in (19), his words should be framed by quotation marks (that we do not find in the text), while, if it was

13 For an analysis of the different functions of the historical present in Italian see Sorella 1983. 
$\overline{\text { From Living Experience to Poetic Word. Frames and Thresholds of Dante's Divine Comedy }}$

Dante-author to speak, the actions narrated in the present should refer to the time of saying/writing (they refer instead to the time of diegetic events). ${ }^{14}$

It would be wrong to understand Dante's use of the historical present merely as a stylistic device. Dante's historical present rather belongs to the functional subclass that linguists sometimes name "dramatic present" and define as follows: "the sudden and temporary insertion of the present tense in a context which narrates a chain of events having taken place in the past" (GGICII 2001: 67; see also Bertinetto 2003). Let us consider, for instance, the incipit of Inferno's canto VI reported in (19). Here the sudden transition from the simple past to the historical (dramatic) present mimics the transition of Dante-character from unconsciousness - he fainted at the end of the preceding canto after hearing the story of Paolo and Francesca - to sensible ("see", "move", "turn", "set the gaze") living experience in all its infernal dramaticity.

We can therefore claim that the degree of permeability that incipits and explicits may introduce between the, otherwise separated, planes of experiencing, remembering and saying/writing reaches its maximum in Dante's uses of the dramatic present which magnify the short circuit between the different dimensions of human cognition, and overcomes the difficulties in their articulation by totally fusing them. In the dramatic present experiencing, remembering and saying coincide as in a kind of live chronicle where all the distances are eliminated. And, just like in any respectable live chronicle, the public of readers/ listeners is also included in such communion:

(20) With me, then, reader raise your eyes / up to the lofty wheels, directly to that part / where the one motion and the other intersect [...] See how from that point / the oblique circle... (PAR X, 7-13)

Here, the stylistic device of a direct dialogue with his reader is not only a sign of the interpolation of Dante-author's voice into the diegetic space; far more, it produces the extra-effect of merging the reader's experience with Dante-character's experience.

14 The historical present in (19) is, by definition, clearly different also from the atemporal present (see (3) above). The latter describes changelessly repeated (habitual) events, while the historical present describes singular events and situations as in (19). 


\title{
Conclusion
}

I have sketched here the general analytical framework to be developed in a more complex study of the function of beginnings and ends as frames and thresholds in the articulation of experience, memory, thought and word in the Divine Com$e d y$; the results of such study need of course to be checked and integrated also by a thorough engagement with previous scholarly research on related aspects of Dante's work. This remained outside the scope of the present article.

As a first, provisional but interesting conclusion of what has been said so far, I would especially highlight the functional duplicity of incipits and explicits at different structural levels of Dante's poem. They work, on the one hand, as modelizing and universalising limits and frames which delimit the diegetic space conferring a final and stable meaning to narrated events; and, on the other hand, as singularizing thresholds which, letting trespass the narrating instance into the diegetic space and the diegetic experience into the narrating instance, problematize both the separateness and the adequate, harmonious articulation of experience and word. Split incipits and explicits are, as we have seen, a particularly efficacious means for staging this duplicity, making it into a mechanism for the generation of narrative tension and expectation. The compared analysis of incipits and explicits of the three canticas and of the interpolations of the narrating voice in incipits and explicits of their cantos allowed us to distinguish different degrees of liminality and permeability of the different structural and functional unities of Dante's poem.

The repeated problematization of the possibilities and limits of the poetic word does not only raise fundamental epistemological questions in the Comedy. It functions, at the same time, as a rhetoric device which sanctions the unprecedented exceptionality of Dante-character's experience and Danteauthor's poetic enterprise. The tension between limit and opening, totality and excess, sayable and unsayable which crosses incipits and explicits at the different structural levels of the Comedy is, in other words, masterfully orchestrated, explored in all its cognitive potential and recomposed by Dante into a complex reflection on power and limits of the poetic word when faced with the most radical human experience.

\author{
Daniele Monticelli \\ daniele@tlu.ee \\ Tallinna Ülikool \\ Narva mnt 29 \\ 10120 Tallinn \\ EESTI
}


From Living Experience to Poetic Word. Frames and Thresholds of Dante's Divine Comedy

\section{References}

Bertinetto, P. M. 2003. Tempi verbali e narrativa italiana dell'Otto-Novecento. Quattro esercizi di stilistica della lingua. Alessandria: Edizioni dell'Orso.

Calvino, I. 1995. Cominciare e finire. - I. Calvino, Saggi 1945-1985 [M. Barenghi, ed.]. Milano: Arnoldo Mondadori Editore.

Contini, G.1970. Varianti e altra linguistica. Torino: Einaudi.

Dante Alighieri 1967. La Divina Commedia [N. Sapegno, ed.]. Firenze: La Nuova Italia Editrice.

Dante Alighieri 2002. The Inferno [R. Hollander, J. Hollander, transl.]. New York: Anchor.

Dante Alighieri 2004. The Purgatorio [R. Hollander, J. Hollander, transl.]. New York: Anchor.

Dante Alighieri 2008. The Paradiso [R. Hollander, J. Hollander, transl.]. New York: Anchor.

Genette, G. 1983. Narrative discourse: an essay in method. Ithaca: Cornell University Press.

Genette, G. 1997. Paratexts: thresholds of interpretation. Cambridge: Cambridge University Press.

GGICII = Renzi, L., Salvi G., Cardinaletti A. (a cura di) 2001. Grande grammatica italiana di consultazione. Vol. II. I sintagmi verbale, aggettivale, avverbiale. La subordinazione. Bologna: Il Mulino.

Greimas, A., Courtés, J. 1982. Semiotics and Language: An Analytical Dictionary. Bloomington: Indiana University Press.

Lotman, Y. M. 1977. The structure of the artistic text [G. Lenhoff, R. Vroon, transl.]. Ann Arbor: University of Michigan Press.

Lotman, Y. 2000. Universe of the mind [A. Shukman, transl.]. Bloomington: Indiana University Press.

Marchese, A. 1978. Dizionario di retorica e di stilistica. Milano: Arnoldo Mondadori Editore.

Monticelli, D. 2009. Crossing Boundaries. Translation of the Untranslatable and (Poetic) Indeterminacy in Juri Lotman and Giacomo Leopardi. - Interlitteraria, 17/2, 327-348.

Reichenbach, H. 1947. Elements of symbolic logics. London: MacMillan.

Sorella, A. 1983. Per un consuntivo degli studi recenti sul presente storico. - Studi di Grammatica Italiana, 12, 307-319. 